
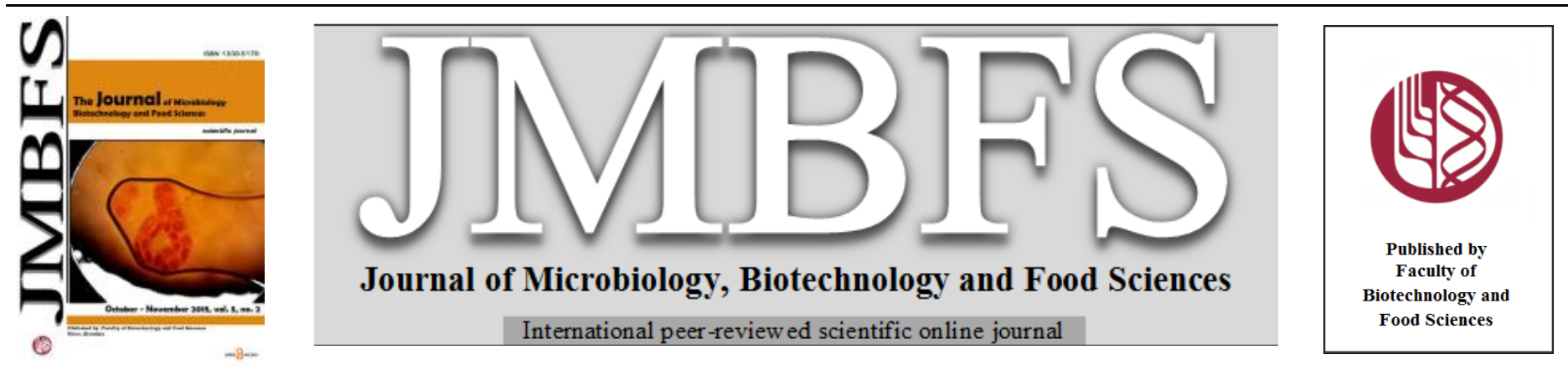

\title{
ISOLATION OF SEED-BORNE AND SEED ASSOCIATED FUNGI OF Lablab purpureus (L.) SWEET AND THEIR BIOLOGICAL CONTROL
}

\author{
Sudhangshu Biswas ${ }^{1}$, Apurba Roy ${ }^{2}$, Rezuanul Islam ${ }^{1}$, Nadia Alam ${ }^{4}$, Samanandro Chowdhury ${ }^{3}$ and Mafizur Rahman ${ }^{*}$
}

\author{
Address(es): \\ ${ }^{1}$ Department of Biotechnology and Genetic Engineering, Islamic University, Kushtia- 7003, Bangladesh. Phone number: +88001712976913. \\ ${ }^{2}$ Department of Genetic Engineering and Biotechnology, University of Rajshahi, Rajshahi-6205, Bangladesh. \\ ${ }^{3}$ Department of Botany, University of Rajshahi, Rajshahi-6205, Bangladesh. \\ 4Human Genome Centre, School of Medical Sciences, University Sains Malaysia, 16150 Kubang, Kelatan, Malaysia.
}

*Corresponding author: shilon83@gmail.com

doi: 10.15414/jmbfs.2015.5.2.136-141

\section{ARTICLE INFO}

Received 10. 7. 2013

Revised 9. 4. 2015

Accepted 30. 6. 2015

Published 1. 10. 2015

Regular article

OPEN $\partial_{\text {ACCESS }}$

\begin{abstract}
Lablab purpureus (L.) Sweet is one of the most important and nutritious vegetables as well as pulse in Bangladesh and is grown extensively all over the country. It suffers from various fungal infections, which reduce greatly its quality and quantity. Seed-borne and seed associated fungi are one of the factors of substantial damages of the bean genotypes. Seed- borne and seed associated fungi of eleven genotypes of $L$. purpureus (L.) Sweet and their various controlling methods were studied. From eleven bean seed samples, seven types of fungal pathogens were isolated and identified. The most predominant fungi species were Aspergillus spp. followed by Fusarium sp. and Rhizopus sp. Comparatively less frequent fungi were Penicillium sp., Curvularia sp., Colletotrichum sp. and Alternaria sp. Plant extracts (Lawsonia inermis, Azadirachta indica and Allium sativum), cow urine, hot water and chemical fungicides (Bavistin, redomil and dithane M-45) were used to observe the efficacy of them against different species of fungi and their effect on germination rate and vigour index of bean seeds. Among the controlling measures, considering fungal infection controlling capacity, germination rate, vigour index as well as cheap, easy, environment friendly, easily available and easily applicable controlling measures, Azadirachta indica leaf extract was the best. Genotype GBLB-6, GBLB-11 and GBLB-13 showed more better performance through all the controlling measures and these genotypes may be used in the breeding program for their higher germination rate, higher vigour index and comparatively lower susceptibility to fungal pathogen.
\end{abstract}

Keywords: L. purpureus (L.) Sweet , fungal pathogen , plant extract, biological control

\section{INTRODUCTION}

Bangladesh is an agricultural country where $85 \%$ of the total population depends upon agriculture. The vegetables and pulses are important crop in our country. $L$. purpureus (L.) Sweet is one of the most important and nutritious vegetables as well as pulse in Bangladesh and is grown extensively all over the country. $L$. purpureus (L.) Sweet belongs to the family Fabaceae (formerly Leguminosae). Commonly it is called Country bean, Lablab bean, Hyacinth bean, Butter bean, Dolichos bean, Sim bean etc. Currently Lablab is one of the major leguminous forage and green manure crop in this area of the world (Cameron, 1988). $L$. purpureus (L.) Sweet has been widely distributed to many tropical and subtropical countries where it has become naturalized. In South and Central America, East and West Indies, Asia, China and India Lablab is grown as an annual or short-lived perennial vegetables. Country bean contains $20-30 \%$ protein on a dry seed, which is nearly three times than in most cereals. Besides this bean contain vitamin A, vitamin $\mathrm{C}$, riboflavin and mineral like magnesium, calcium, phosphorus, potassium, iron, sulphur and sodium (Jukanti et al, 2012, Deka and Sarkar, 1990). Apart from L. purpureus (L.) Sweet provide significant nutritional and health benefits, and are known to reduce several noncommunicable diseases such as colon cancer and cardiovascular diseases (Yude et al,1993; Jukanti et al,2012). In addition to, the use of phosphate solubilizing bacteria for instance, Pseudomonas, Bacillus and Rhizobium are among the most powerful phosphate $(\mathrm{P})$ solubilizers, as inoculants simultaneously increases $\mathrm{P}$ uptake by the plant and thus crop yields (Khan et al, 2009). For this, the richness of legumes in $\mathrm{N}$ and $\mathrm{P}$ makes them attractive for insect pests and diseases (Sinclair and Vadez, 2012). More over the natural action of converting atmospheric nitrogen into forms available for the plant-animal-soil system improves productivity is an inexpensive, environmentally friendly manner. Usually $15-40 \mathrm{~kg}$ nitrogen is fixed for each $1000 \mathrm{~kg}$ dry matter of shoots grown (Humphreys, 1995).
Seed is the basic unit in crop production. Seeds play a vital role in associating microorganisms, which prove hazardous for the seed or the new plant product from it. The associated microorganisms may be pathogenic, weak parasite or saprophytes, they may be associated internally or externally with the seed or as concomitant contamination as sclerotia, galls, fungal bodies, infected plant parts, soil particles etc. are mixed with the seed. The seed-borne as well as seed associated fungal infection can be effectively reduced if the seeds are treated by fungicide before sowing. But the indiscriminate use of the fungicide has been cautioned as some of these are found to have various harmful residual effects on the surrounding environment (Beye, 1978). Further due to the development of new physiological race of pathogen, many of the synthetic fungicides are gradually becoming ineffective (Wellman, 1977).

In recent year, some research on the fungal toxicity of extracts of various parts of higher plant have indicated the possibility of their exploitation as natural fungal toxicant for controlling plant diseases (Misra and Dixit, 1977; Naidu and John, 1981; Agrawal and Rai, 1984; Anwar et al. 1994). Plant extracts are cheap, can be easily prepared and used whenever required. In fact some workers have already demonstrated the successful use of crop plant (Singh $\boldsymbol{e t}$ al. 1990; Gupta, 1997). Lawsonia inermis, Azadirachta indica and Allium sativum may hinder the pathogenic growth, which has been claimed by some worker. Some scientist reported the antimicrobial, antibacterial and anti-fungal properties of leaf extracts of Lawsonia inermis (Malekzadeh and Shabestari, 1989). Animal byproduct such as cow urine (Basak and Lee 2001b) and physical treatment such as dipping the seeds into hot water are also used to protect seed-borne and seed associated microorganisms (Lambat et al. 1974).

The aim of our study was to isolate the seed-borne and seed associated fungi of Country bean and evaluate the efficacy of some plant extracts with some treatments like cow urine treatment and hot water treatment as fungal toxicants against the existing fungi and to assess the extent of phytotoxicity if any of them with good fungitoxic effect on germination and vigour index. 


\section{MATERIAL AND METHODS}

\section{Sample collection}

In this study, eleven genotypes of $L$. purpureus (L.) Sweet were collected from different districts from northern region in Bangladesh. Then the seed samples were labeled properly and named as (Genetics and breeding laboratory-2), GBLB-2, GBLB-3, GBLB-5, GBLB-6, GBLB-7, GBLB-9, GBLB-11, GBLB-12, GBLB-13, GBLG-14 and GBLB-15 with date for future reference.

\section{Seed test}

For seed test, dry examination, blotter method and agar plate method were applied for seed health testing.

\section{Identification of fungal colony}

Identification of fungal colony was made microscopically. The generic identification of each colony was recorded and identification up to species level was tried wherever possible with the help of standard Mycological book and manual (Gilman, 1971; Ellis, 1971 and Alexopoulos, 1979).

\section{Plant extracts preparation for treatment}

Extractions of plant bulbs and leaf tissues in water and alcohol used as fungicides were done the method with some modifications which are described by Mohadevan and Sridhar (1982). At first five gram tissues were cut into pieces and immediately plunged in water in a beaker and allowed to boil for 5 minutes using 5-10 $\mathrm{ml}$ of alcohol for every gram tissue. Then the extraction was done on top of a stem bath. The extraction was cooled in a pan of cold water After that, the tissues were crushed thoroughly in a motor with a pestle and then passed through two layer of cheese cloth and re-extracted the ground tissues for 3 minutes in distilled water, using $2-3 \mathrm{ml}$ of water for every gm of tissue. The second extraction ensured complete removal of alcohol soluble substance. Cooled and passed through cheese cloth. Cooled both extracts and filtered through Whatman's No 1 filter paper. The volume of the extract was evaporated on a stem bath to dryness. Two hundred $\mathrm{ml}$ distilled water was added for $5 \mathrm{gm}$ of tissue and prepared $2.5 \%$ plant extracts. Similarly $1.5 \%$ and $2.0 \%$ of plant extracts were made to test the efficacy in different concentration. Evaluation of different percentage of plant extracts was done in the laboratory by the blotter method. The seeds were dipped 5 minutes in different concentrations of plant extracts for treatment (Alam et al. 2002).

\section{Cow urine treatment}

Different concentrations of cow urine solution in combination with sterile distilled water were (30:70, 45:55, 60:40) used for the control of seed-borne as well as seed associated fungi on different genotypes of country bean. 30, 45, and $60 \mathrm{ml}$ of cow urine $\left(\mathrm{P}^{\mathrm{H}}\right.$ 9.20) diluted with sterilized distilled water for the preparation of 30:70, 45:55, 60:40 solutions according to Basak and Lee (2001b). The seeds were dipped 1 hour in different concentrations of cow urine.

\section{Hot water treatment}

For hot water treatment, seeds were surface sterilized by distilled water and this were taken in sterilized test tube with three replicated. Then test tubes were immersed in water bath of $50^{\circ} \mathrm{C}$ and treated at different time $(15 \mathrm{~min}$., $30 \mathrm{~min}$., $45 \mathrm{~min}$. and $60 \mathrm{~min}$.) with control. The treated seeds were removed from the water bath and placed in autoclaved petridishes, which were made moisture chamber by using blotting paper soaked with sterilized distilled water. After 7 days of incubation in $25^{\circ} \mathrm{C}$ temperature all the petridishes were examined, is there any growth of fungi or not.

\section{Chemical treatment}

Three chemical fungicides Bavistin DF (Methyl-2-benzimidazole carbamate) Redomil MZ [(Complex of methyl-D) L-N (2, 6-Dimethyl Phenyl) -N (2Methobis-acetyl alaninite, Zinc salt and polymeric Manganese ethylene bis (Dithiocarbamate)] and Dithane M-45 (Manganese ethylene bisdithio carbamate plus zinc) were used. The seeds were treated with these chemicals at the rate of 0.25 percent according to Bkar (1988) and Jain and Khare (1972). Seeds were taken in $100 \mathrm{ml}$ conical flask and required amount of fungicide was added to it. The mixture was then shaken for $15 \mathrm{~min}$. in a mechanical shaker. After $5 \mathrm{~min}$. of treatment, the treated seeds were used for studying the efficacy of the fungicides.

\section{RESULTS AND DISCUSSION}

In this experiment, seed borne and seed associated fungal pathogen of eleven genotypes of $L$. purpureus (L.) Sweet was studied and their various controlling methods were applied. From eleven bean seed samples seven types of fungal pathogens were isolated and identified. These were Aspergillus sp., Penicillium sp., Fusarium sp., Curvularia sp., Rhizopus sp., Colletotrichum sp. and Alternaria sp. The most predominant fungi species was Aspergillus sp. followed by Fusarium sp. and Rhizopus sp. Results are shown in the Tab 1, figure-A, B and $\mathrm{C}$.

Saprophytic invasion of species Aspergillus and Penicillium have great potentiality to destroy embryos of the seed and thus reduce seed germination. So, it is not always the pathogenic seed borne fungi, which is responsible to reduce seed germination. Similar observations were followed by (Neergaard, 1980; Reddy and Khare, 1978; Khare et al. 1988; Christensen, 1973).

Plant extracts, Cow urine, hot water and chemical fungicides were applied to observe the efficacy of them against different species of fungi. The influence of seed germination rate and vigour index was also studied through treatment. In the three plant extracts (mehndi leaf, neem leaf and garlic bulb) treatments among the three concentrations the $2.5 \%$ concentration was the best because in this concentration the fungal infections were controlled significantly and expected seed germination rate as well as vigour index were observed higher. Considering germination rate, vigor index and percentage of fungal infection altogether in three concentrations of the three plant extracts, genotype GBLB-6, GBLB-11 and GBLB-13 showed better performance than others.

In Mehendi, Neem leaf and garlic bulb extract treatment it was found that treated seed in $2.5 \%(99.5 \pm 0.4 ; 98.5 \pm 0.7 ; 97.9 \pm 0.7)$ on the other hand $2.0 \%(99.2 \pm 4$; $98.9 \pm 0.5 ; 99.6 \pm 0.2)$ concentration showed good result on seed germination respectively. The $2.5 \%$ concentration showed successful control of fungal infection $(0.00-9.90 \% ; 0.00-6.60 \% ; 0.00-9.90 \%)$ with higher vigour index $(1196.8 \pm 74.2 ; 1602.4 \pm 131.2 ; 1243.7 \pm 103.0)$ respectivly (Tab-2, 4). Some scientist reported the antimicrobial, antibacterial and anti-fungal properties of leaf extracts of Mehendi (Malekzadeh and Shabestari, 1989 and Rosenberg, 1999). Khan and Kumar (1990) conducted an experiment to find the antifungal activity of leaf extracts of Neem (A. indica) on wheat seeds mycoflora, using different dilutions. They reported that, treatment caused a marked reduction in seed mycoflora and enhanced seed germination. In Bangladesh Hasan et al. (2005) conducted a research on antifungal effects of ten plant extracts on wheat seed germination and among all of them Neem (A. indica) leaf extracts showed best result which one similar to our result. Moreover, Suratuzzaman (1995) performed an experiment to control seed-borne Collectotrichum dematium var. truncatum, Macrophomina phaseolina and Cercospora kikuchii of Soybean seed and Garlic and Ginger extracts, gave excellent control of the pathogens.

Among different concentrations in Cow urine treatment (Table-2) the $45 \%$ concentration showed reduction of fungal infection (6.60-23.10\%) with higher average vigour index (1342.8 \pm 96.3$)$ (Table-4). In 60\% concentration though the fungal infection $(3.30 \pm 9.90)$ was controlled successfully, the average germination rate $(68.7 \pm 1.7)$ and average vigour index $(295.0 \pm 32.6)$ were reduced remarkably (Table-4). Basak and Lee (200lb) performed an experiment by using cow urine for controlling Fusarium wilt caused by Fusarium oxysporum Sankaranarayanan et al. 1994 found that Tamarind seeds have a hard seed coat that causes slow and poor germination. Soaking the seeds in $10 \%$ cow urine or in cowdung solution (500 g in 10 litres of water) for $24 \mathrm{~h}$ increased the germination percentage from $37 \%$ (untreated controls) to 72.6 and $82.8 \%$, respectively. 
Table 1 Abundance of external and internal seed associated fungi of eleven genotypes of Country bean.

\begin{tabular}{|c|c|c|c|c|c|c|c|c|c|c|c|}
\hline \multirow[b]{2}{*}{ 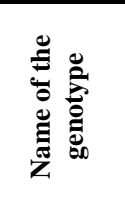 } & \multirow[b]{2}{*}{ 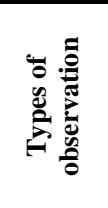 } & \multirow[b]{2}{*}{ 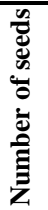 } & \multirow[b]{2}{*}{ 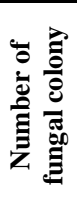 } & \multicolumn{7}{|c|}{ Name and colony number of isolated fungi } & \multirow[b]{2}{*}{ 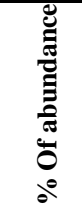 } \\
\hline & & & & 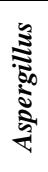 & 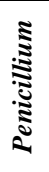 & 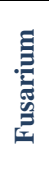 & $\frac{0}{\sqrt[3]{5}}$ & 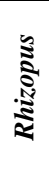 & 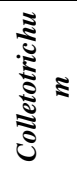 & 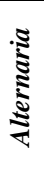 & \\
\hline \multirow{2}{*}{ GBLB-2 } & External & 03 & 10 & 3 & 1 & 2 & 0 & 2 & 1 & 1 & 333.33 \\
\hline & Internal & 03 & 14 & 5 & 2 & 3 & 1 & 2 & 1 & 0 & 466.66 \\
\hline \multirow{2}{*}{ GBLB-3 } & External & 03 & 7 & 3 & 0 & 2 & 0 & 2 & 0 & 0 & 233.33 \\
\hline & Internal & 03 & 16 & 6 & 2 & 4 & 1 & 3 & 0 & 0 & 533.33 \\
\hline \multirow{2}{*}{ GBLB-5 } & External & 03 & 10 & 3 & 2 & 2 & 1 & 2 & 0 & 0 & 333.33 \\
\hline & Internal & 03 & 12 & 3 & 0 & 4 & 0 & 2 & 1 & 2 & 400.00 \\
\hline \multirow{2}{*}{ GBLB-6 } & External & 03 & 7 & 2 & 0 & 0 & 0 & 4 & 1 & 0 & 233.33 \\
\hline & Internal & 03 & 8 & 1 & 0 & 2 & 0 & 4 & 0 & 1 & 266.66 \\
\hline \multirow{2}{*}{ GBLB-7 } & External & 03 & 7 & 2 & 2 & 1 & 2 & 0 & 0 & 0 & 233.33 \\
\hline & Internal & 03 & 15 & 5 & 2 & 3 & 2 & 0 & 2 & 0 & 500.00 \\
\hline \multirow{2}{*}{ GBLB-9 } & External & 03 & 14 & 4 & 3 & 3 & 1 & 1 & 2 & 0 & 466.66 \\
\hline & Internal & 03 & 13 & 3 & 1 & 3 & 2 & 2 & 0 & 2 & 433.33 \\
\hline \multirow{2}{*}{ GBLB-11 } & External & 03 & 5 & 0 & 2 & 2 & 0 & 0 & 1 & 0 & 166.66 \\
\hline & Internal & 03 & 6 & 1 & 0 & 1 & 0 & 2 & 1 & 1 & 200.00 \\
\hline \multirow{2}{*}{ GBLB-12 } & External & 03 & 6 & 2 & 1 & 1 & 1 & 0 & 0 & 1 & 200.00 \\
\hline & Internal & 03 & 12 & 4 & 3 & 2 & 0 & 2 & 0 & 1 & 400.00 \\
\hline \multirow{2}{*}{ GBLB-13 } & External & 03 & 4 & 2 & 0 & 1 & 0 & 1 & 0 & 0 & 133.33 \\
\hline & Internal & 03 & 12 & 3 & 0 & 2 & 2 & 1 & 1 & 3 & 400.00 \\
\hline \multirow{2}{*}{ GBLB-14 } & External & 03 & 14 & 5 & 1 & 2 & 2 & 3 & 0 & 1 & 466.66 \\
\hline & Internal & 03 & 16 & 6 & 0 & 4 & 2 & 2 & 2 & 0 & 533.33 \\
\hline \multirow[t]{3}{*}{ GBLB-15 } & External & 03 & 8 & 0 & 0 & 3 & 0 & 3 & 0 & 2 & 266.66 \\
\hline & Internal & 03 & 13 & 7 & 2 & 0 & 2 & 0 & 1 & 1 & 433.33 \\
\hline & Total & 66 & 228 & 70 & 24 & 47 & 19 & 38 & 14 & 16 & - \\
\hline
\end{tabular}

Table 2 Percentage of fungi infected seed after different treatment with control of eleven genotypes of Country bean

\begin{tabular}{|c|c|c|c|c|c|c|c|}
\hline \multirow{3}{*}{ Genotypes } & \multirow{3}{*}{ Control } & \multicolumn{6}{|c|}{ Treatment } \\
\hline & & \multicolumn{3}{|c|}{ Plant Extracts } & \multirow[b]{2}{*}{ Animal byproduct } & \multirow[b]{2}{*}{ Physical treatment } & \multirow[b]{2}{*}{ Chemical treatment } \\
\hline & & $\begin{array}{l}\text { Mehendi } \\
\text { Leaf }\end{array}$ & Neem leaf & Garlic bulb & & & \\
\hline GBLB-2 & 62.70 & 3.30 & 3.30 & 6.60 & 23.10 & 9.90 & 0.00 \\
\hline GBLB-3 & 62.70 & 6.60 & 6.60 & 0.00 & 19.80 & 9.90 & 0.00 \\
\hline GBLB-5 & 56.10 & 3.30 & 6.60 & 6.60 & 19.80 & 9.90 & 0.00 \\
\hline GBLB-6 & 29.70 & 0.00 & 6.60 & 0.00 & 13.20 & 13.20 & 0.00 \\
\hline GBLB-7 & 46.20 & 9.90 & 3.30 & 3.30 & 13.20 & 6.60 & 0.00 \\
\hline GBLB-9 & 33.00 & 3.30 & 3.30 & 3.30 & 19.80 & 13.20 & 0.00 \\
\hline GBLB-11 & 49.50 & 3.30 & 0.00 & 0.00 & 16.50 & 9.90 & 0.00 \\
\hline GBLB-12 & 62.70 & 6.60 & 6.60 & 3.30 & 9.90 & 3.30 & 0.00 \\
\hline GBLB-13 & 33.00 & 0.00 & 0.00 & 0.00 & 6.60 & 3.30 & 0.00 \\
\hline GBLB-14 & 33.00 & 3.30 & 3.30 & 9.90 & 9.90 & 9.90 & 0.00 \\
\hline GBLB-15 & 56.10 & 3.30 & 3.30 & 0.00 & 9.90 & 13.20 & 0.00 \\
\hline
\end{tabular}

Legend: GBLB- Genetics and breeding laboratory, Chemical treatment (Bavistin, dithane M-45, redomil), Physical treatment (Hot water), Animal byproduct(cow urine)

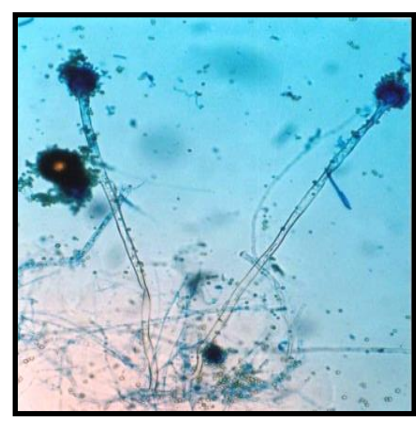

$\mathbf{A i}$

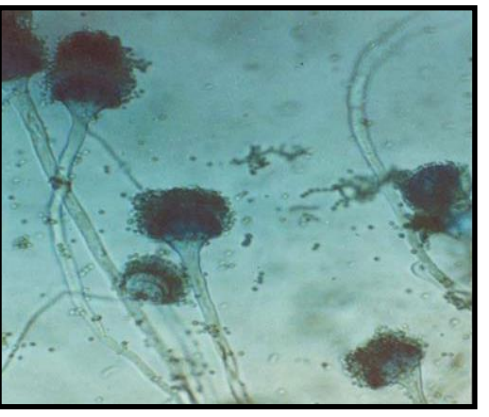

A ii

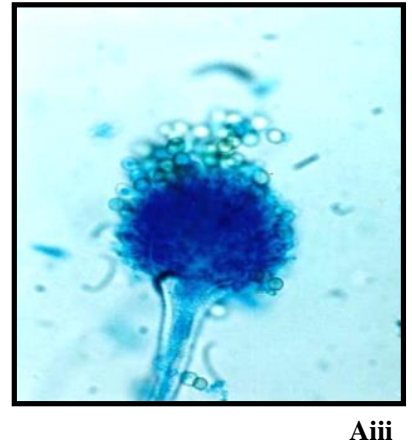




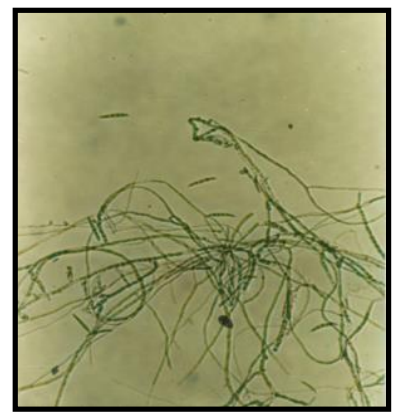

Bi

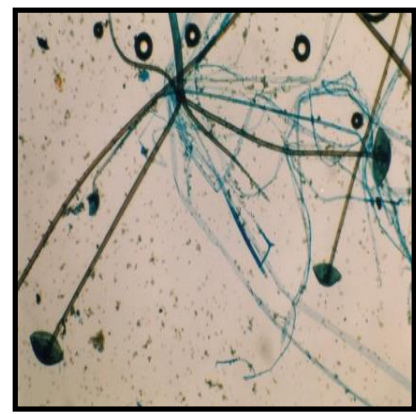

Ci

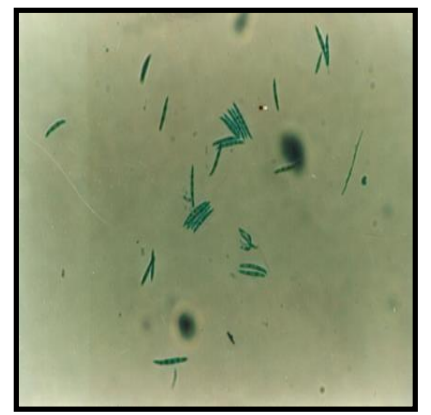

B ii

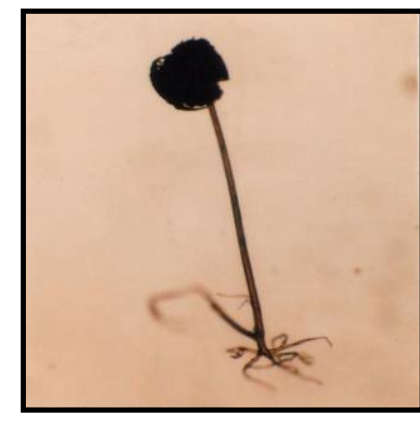

C ii

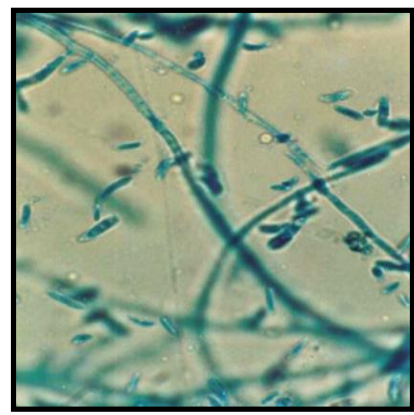

B iii

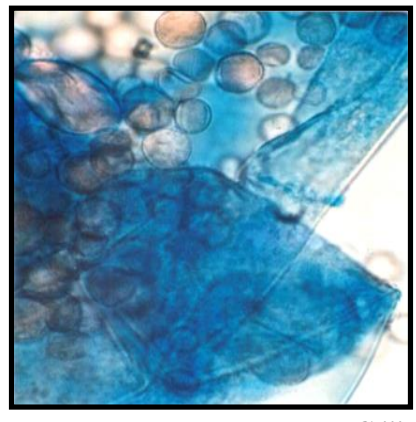

C iii

Figure-A. Different stages of Aspergillus sp conidiophores with conidia in chain. (i) $(2.5 \times 20 \mathrm{X})$ (ii) $(2.5 \times 40 \mathrm{X})$ (iii) $(2.5 \times 100 \mathrm{X})$ Figure-B. Different stages of Fusarium sp conidiophores with conidia (i) $(2.5 \times 20 \mathrm{X})$ (ii) Conidia $(2.5 \times 40 \mathrm{X})$ (iii) $(2.5 \times 100 \mathrm{X})$ Figure-C. Different stages of Rhizopus sp. Sporangiophore with sporangium (i) $(2.5 \times 20 \mathrm{X})$ (ii) $(2.5 \times 20 \mathrm{X})$ (iii) Exposed sporangium with spores $(2.5 \times 100 \mathrm{X})$.

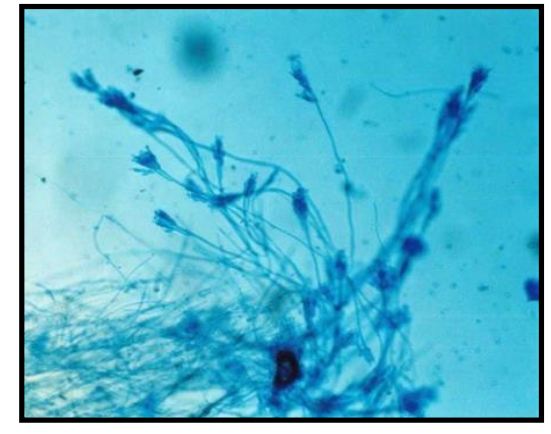

(D.i)
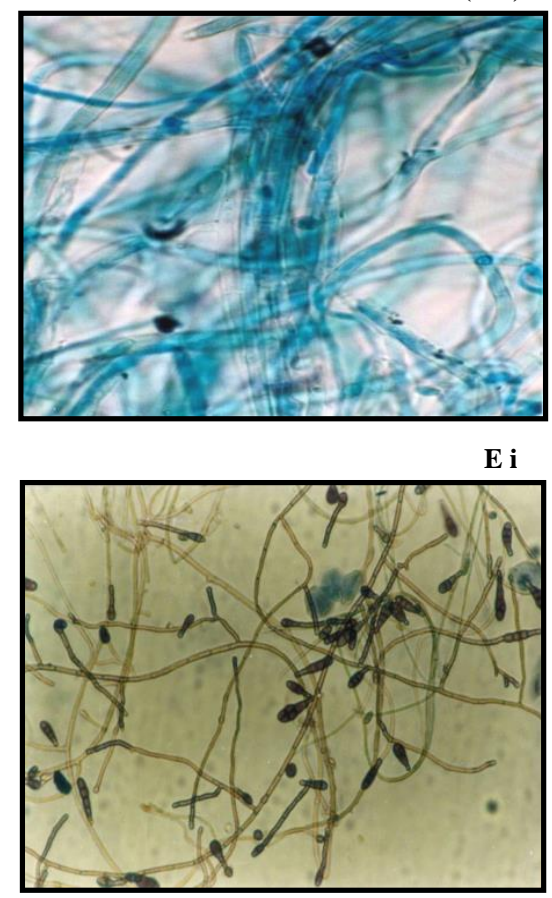

$\mathbf{F} \mathbf{i}$

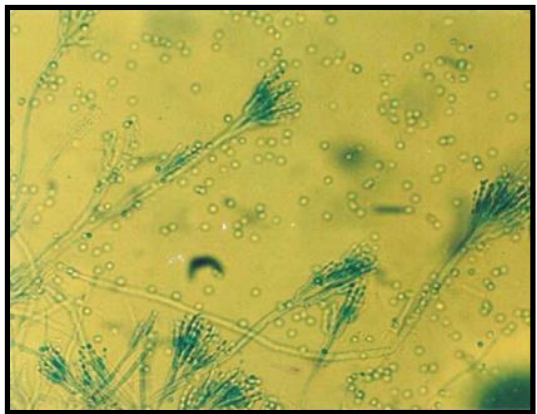

(D.ii)

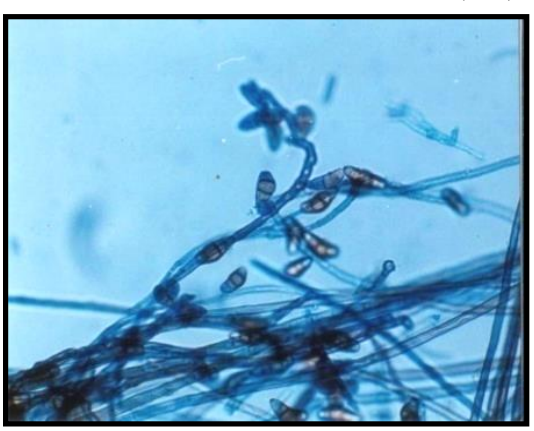

E ii

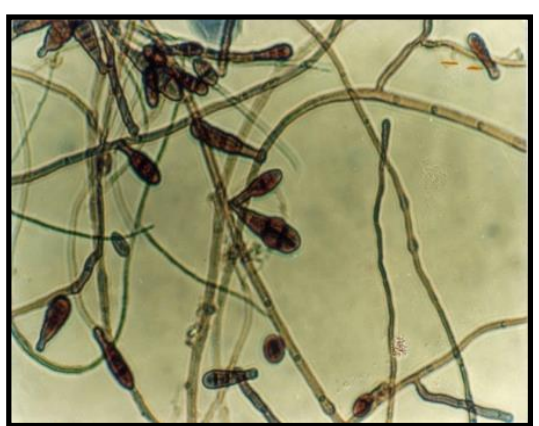

F ii

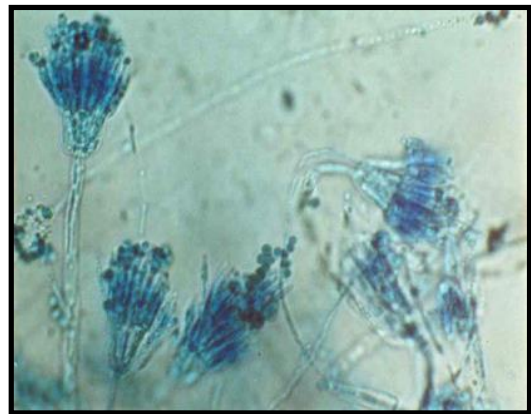

(D.iii)

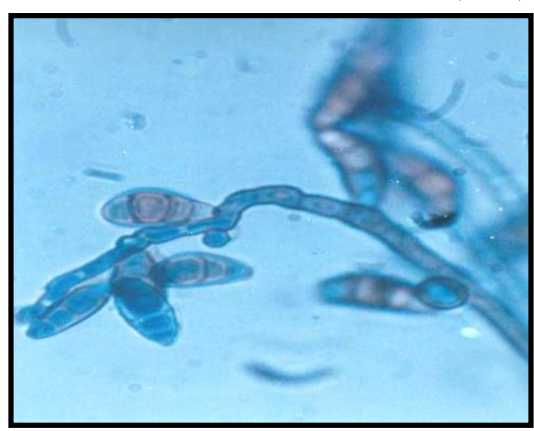

F iii

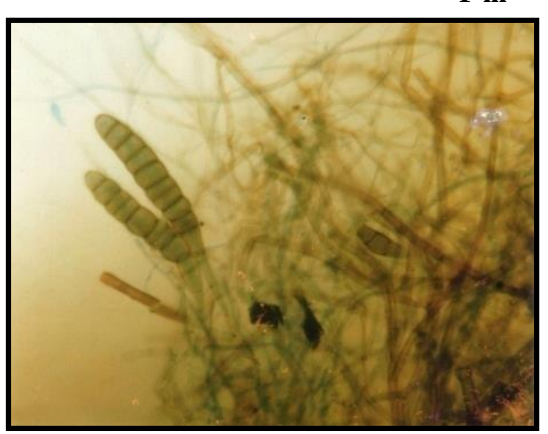

F iii 

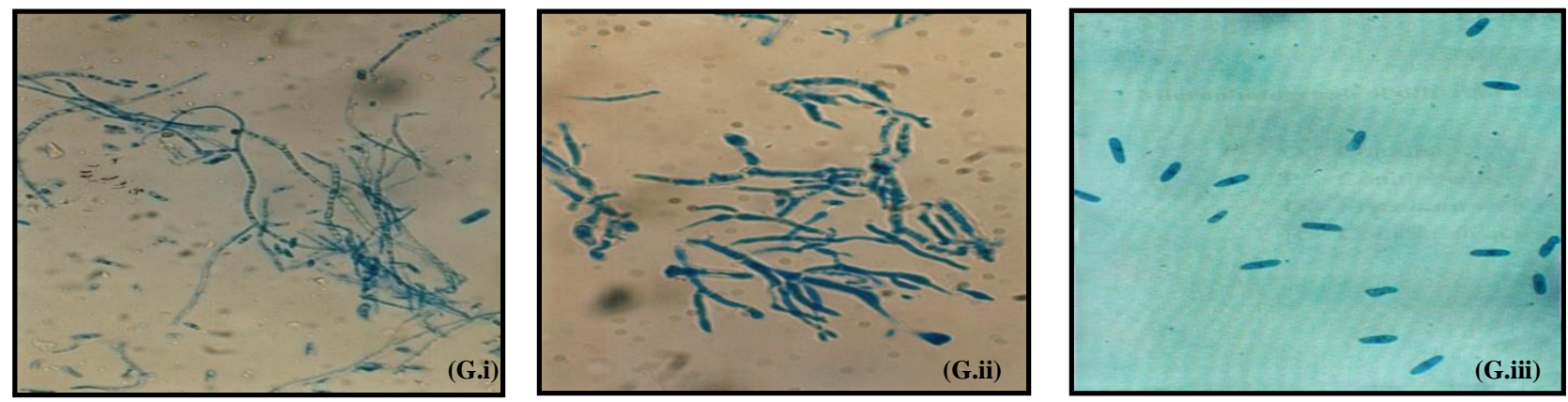

Fig-D. Different stages of Penicillium sp. Conidiophores with conidia in chain (D.i) $(2.5 \times 20 X)($ D.ii) $(2.5 \times 40 X)($ D.iii $)(2.5 \times 100 X)$ Fig-E. Different stages of Curvularia sp.Conidiophores with conidia (E.i) $(2.5 \times 20 \mathrm{X})$ (E.ii) $(2.5 \times 40 \mathrm{X})$ (E.iii) $(2.5 \times 100 \mathrm{X})$ Fig-F. Different stages of Alternaria sp. Conidiophores with conidia(F.i) $(2.5 \times 20 \mathrm{X})($ F.ii $)(2.5 \times 40 \mathrm{X})($ F.iii $)(2.5 \times 100 \mathrm{X})$ Fig-G. Different stages of Colletotrichum sp.Conidiophores with conidia $(\mathrm{G} . \mathrm{i})(2.5 \times 20 \mathrm{X})(\mathrm{G} . \mathrm{ii})(2.5 \times 40 \mathrm{X})$ (G.iii) $(2.5 \times 40 \mathrm{X})$

In hot water treatment $\left(50^{\circ} \mathrm{C}\right)$ in $(\mathrm{Tab}-2)$ it was observed that treated seeds in 30 min. (98.645 \pm 0.555$)$ and $45 \mathrm{~min}$. (97.172 \pm 0.728$)$ immersion period showed good result of average seed germination as well as successful control of fungal infection (3.30-13.20\% and 0.00-9.90\% respectively) (Tab-2).

On the other hand seed treatment in $60 \mathrm{~min}$. immersion period controlled the fungal infections completely but it reduced seed germination remarkably (17.400 \pm 1.206 ) (Table-2). Lambat et al. (1974) reported eradication of Phomabetae in sugar beet seed by hot water treatment at $50^{\circ} \mathrm{C}$ for $30 \mathrm{~min}$.

Treatment of seeds by chemical fungicides it was observed that, in case of Redomil and Dithane M-45 treatment the fungal infection were controlled completely and the germination rate of seed was $(99.3 \pm 0.4)$ and $(98.0 \pm 0.7)$ respectively (Table-3). In Bavistin, the fungal pathogen was controlled successfully $(0.00-6.60 \%)$ (Table-2) but not completely and the germination rate of seed was $90.600 \pm 0495$. The values of vigour index were $1131.5 \pm 117.2$, $1234.0 \pm 108.2$ and 1056.9 \pm 84.3 in the treatment of Bavistin, Redomil and Dithane M-45 respectively (Table-4). Singh and Singh (1986) reported similar result on seed treatment of Broad bean (Vicia feba) with Dithane M-45, Ceresan dry, Bavistin and Vitavax was evaluated for their reducing seed mycoflora.

Table 3 Seed germination rate of $L$. purpureus (L.) Sweet after different treatment

\begin{tabular}{|c|c|c|c|c|c|c|c|}
\hline \multirow{3}{*}{ Genotypes } & \multirow{3}{*}{ Control } & \multicolumn{6}{|l|}{ Treatment } \\
\hline & & \multicolumn{3}{|c|}{ Plant Extracts } & \multirow[b]{2}{*}{ Cow urine } & \multirow{2}{*}{$\begin{array}{l}\text { Hot water } \\
\text { treatment }\end{array}$} & \multirow{2}{*}{$\begin{array}{c}\text { Average } \\
\text { value of three } \\
\text { chemical } \\
\text { treatments }\end{array}$} \\
\hline & & Mehendi leaf & Neem leaf & Garlic bulb & & & \\
\hline GBLB-2 & 79.20 & $94.6 \pm 2.4$ & $95.7 \pm 2.7$ & $97.1 \pm 2.0$ & $88.0 \pm 7.0$ & $75.3 \pm 17.1$ & $97.4 \pm 2.0$ \\
\hline GBLB-3 & 69.30 & $94.9 \pm 2.6$ & $96.0 \pm 2.8$ & $94.6 \pm 2.4$ & $83.6 \pm 10.0$ & $74.8 \pm 18.9$ & $96.0 \pm 2.8$ \\
\hline GBLB-5 & 72.60 & $95.7 \pm 2.8$ & $95.7 \pm 1.6$ & $95.7 \pm 2$. & $88.3 \pm 9.1$ & $73.5 \pm 18.5$ & $96.0 \pm 2.8$ \\
\hline GBLB-6 & 82.50 & $96.0 \pm 2.8$ & $96.4 \pm 2.97$ & $96.4 \pm 3.0$ & $92.0 \pm 6.5$ & $77.0 \pm 16.6$ & $97.1 \pm 1.9$ \\
\hline GBLB-7 & 75.90 & $97.5 \pm 2.1$ & $94.6 \pm 2.4$ & $95.7 \pm 1.6$ & $86.9 \pm 5.9$ & $74.3 \pm 16.8$ & $95.7 \pm 2.7$ \\
\hline GBLB-9 & 79.20 & $97.1 \pm 1.9$ & $97.1 \pm 1.95$ & $96.0 \pm 2.8$ & $85.8 \pm 6.8$ & $75.9 \pm 15.3$ & $94.6 \pm 2.4$ \\
\hline GBLB-11 & 85.80 & $96.4 \pm 3.00$ & $97.1 \pm 1.95$ & $97.5 \pm 2.7$ & $91.6 \pm 6.4$ & $78.0 \pm 16.9$ & $98.6 \pm 1.1$ \\
\hline GBLB-12 & 79.20 & $96.4 \pm 3.0$ & $92.4 \pm 1.56$ & $96.0 \pm 1.8$ & $84.7 \pm 10.4$ & $77.2 \pm 16.7$ & $97.1 \pm 1.9$ \\
\hline GBLB-13 & 82.50 & $96.0 \pm 2.8$ & $96.4 \pm 3.0$ & $96.0 \pm 2.8$ & $88.3 \pm 9.1$ & $76.9 \pm 17.5$ & $96.0 \pm 2.8$ \\
\hline GBLB-14 & 69.30 & $97.5 \pm 2.1$ & $96.8 \pm 1.8$ & $94.6 \pm 1.8$ & $84.7 \pm 6.3$ & $75.0 \pm 16.0$ & $97.4 \pm 2.7$ \\
\hline GBLB-15 & 75.90 & $96.4 \pm 2.9$ & $97.47 \pm 2.1$ & $96.4 \pm 4.0$ & $86.9 \pm 6.3$ & $75.9 \pm 16.2$ & $96.0 \pm 2.8$ \\
\hline Mean \pm SE & $76.8 \pm 1.4$ & $96.2 \pm 0.3$ & $96.0 \pm 0.4$ & $96.0 \pm 0.3$ & $87.4 \pm 0.8$ & $75.8 \pm 0.4$ & $96.5 \pm 0.2$ \\
\hline
\end{tabular}

Legend: GBLB - Genetics and breeding laboratory, Chemical treatment (Bavistin, dithane M-45, redomil)

Table 4 Vigour index of L. purpureus (L.) Sweet after different treatments

\begin{tabular}{|c|c|c|c|c|c|c|c|}
\hline \multirow{3}{*}{ Genotypes } & \multirow{3}{*}{ Control } & \multicolumn{6}{|l|}{ Treatment } \\
\hline & & \multicolumn{3}{|c|}{ Plant Extracts } & \multirow{2}{*}{ Cow urine } & \multirow{2}{*}{$\begin{array}{l}\text { Hot water } \\
\text { treatment }\end{array}$} & \multirow{2}{*}{$\begin{array}{c}\text { Average Value of } \\
\text { three chemical } \\
\text { treatments }\end{array}$} \\
\hline & & Mehendi leaf & Neem leaf & Garlic bulb & & & \\
\hline GBLB-2 & 150.45 & $730.7 \pm 301.2$ & $1458.1 \pm 331.9$ & $1046.1 \pm 142.7$ & $933.1 \pm 283.2$ & $842.7 \pm 244.2$ & $1123.1 \pm 108.3$ \\
\hline GBLB-3 & 227.70 & $691.3 \pm 222.5$ & $1440.1 \pm 81.8$ & $775.7 \pm 106.8$ & $841.0 \pm 254.1$ & $742.4 \pm 217.3$ & $1119.8 \pm 143.0$ \\
\hline GBLB-5 & 138.60 & $490.1 \pm 146.0$ & $1131.1 \pm 40.7$ & $1052.6 \pm 30.6$ & $812.0 \pm 220.1$ & $693.3 \pm 196.7$ & $990.1 \pm 65.6$ \\
\hline GBLB-7 & 346.50 & $684.7 \pm 175.8$ & $945.0 \pm 80.2$ & $905.8 \pm 75.7$ & $745.3 \pm 220.4$ & $1084.7 \pm 298.9$ & $974.7 \pm 29.5$ \\
\hline GBLB-9 & 415.87 & $858.8 \pm 173.8$ & $1059.9 \pm 55.5$ & $873.2 \pm 41.6$ & $814.3 \pm 199.6$ & $992.6 \pm 292.7$ & $1057.8 \pm 182.4$ \\
\hline GBLB-11 & 316.80 & $1096.0 \pm 152.4$ & $1895.3 \pm 185.5$ & $1578.4 \pm 218.6$ & $1204.9 \pm 325.9$ & $1095.9 \pm 326.3$ & $1547.7 \pm 238.2$ \\
\hline GBLB-12 & 217.80 & $584.6 \pm 160.8$ & $1700.9 \pm 46.5$ & $1161.0 \pm 96.9$ & $850.8 \pm 313.7$ & $986.1 \pm 267.9$ & $1087.5 \pm 68.3$ \\
\hline GBLB-13 & 206.25 & $1154.2 \pm 127.9$ & $1720.7 \pm 181.5$ & $1418.7 \pm 158.6$ & $1347.2 \pm 398.5$ & $1101.3 \pm 326.4$ & $1559.0 \pm 53.9$ \\
\hline GBLB-14 & 519.75 & $971.3 \pm 132.5$ & $1081.3 \pm 36.4$ & $936.9 \pm 68.5$ & $940.5 \pm 228.5$ & $1066.6 \pm 313.3$ & $685.4 \pm 72.4$ \\
\hline
\end{tabular}

Legend: GBLB - Genetics and breeding laboratory, Chemical treatment (Bavistin, Dithane M-45,Redomil).

\section{CONCLUSION}

Chemical fungicide showed complete control of fungi. But chemical fungicides are costly and harmful to health and environment. Now a days the scientists demand cheap, easy and environment friendly controlling measures. Taking all these things into consideration the Plant extracts and Hot water treatment are the suitable controlling measures. In both cases though the fungal pathogens were not controlled completely but successfully. In the three plants extract treatment (Mehendi, Neem and Garlic) the $2.5 \%$ concentration showed the best result in controlling fungal infection and increased seed germination rate as well as vigour index. By giving emphasis on germination rate, vigour index and fungal infection controlling capacity; cheap, A. indica environment friendly, easily available and easily applicable controlling measure; $A$. indica leaf extract was the best among the three plant extracts. 


\section{REFERENCES}

AGARWAL, P., RAI, B. 1984. Effect of bulb extracts of onion and garlic on soil Bacteria. Acta Botanica India, 12, 45-49.

ALAM, S., AKTHER, N., BEGUM, F., BANU, S., ISLAM, R., CHOWDHURY, N., ALAM, S. 2002. Antifungal activities (in vitro) of some plant extracts and smoke on four fungal pathogens of different hosts. Pakistan Journal of Biological Science, 5(3), 307-309. http://dx.doi.org/10.3923/pjbs.2002.307.309

ALEOXOPOLOUS, J., MIMS, W. 1979. Introductory Mycology. Third Edi. John Wiley and Sons. Inc. USA, 632p. http://dx.doi.org/10.1002/ips.3030420228 ANWAR, N., SINGPHA, P., BEGUM, J., CHOWDHURY, J. 1994. Antifungal activity of some selected plant extracts on phytopathogenic fungi. Bangladesh Journal of Life Science, 6, 23-26.

BAKR, A. 1988. Effect of presowing chemical seed treatment in controlling collar rot disease of Chickpea. Abs. Bangladesh Science Conference, 13 (Section 1), 90p. http://dx.doi.org/oar.icrisat.org/535/1/RA_00152

BASAK, A.B., LEE, M.W. 2002. In vitro activity of cow urine and cow dung for controlling Fusarium solanif. sp. cucurbitae of cucumber. Mycobiology, 30(1), 51-54. http://dx.doi.org/10.4489/myco.2002.30.1.051

BEYE, F. 1978. Insecticides from the vegetable kingdom. Plant Research and Development, 7, 13-31.

BOKHARY, H. 1991. Seed borne fungi of rice, Zeitschrift fur Pflanzenkram Kheiten and Planzenschutf, 98(3), 287-292.

CAMERON, G. 1988. Tropical and subtropical pasture legumes, Queens Agricultural Journal, 110-113.

CHRISTENSEN, M. 1973. Loss of viability in storage: Mycoflora. Seed Science and Technology, 1, 547-562. http://dx.doi.org/10.1242/iosr/P07399103

DEKA, R., SARKER, R. 1990. Nutritional composition and anti-nutritional factors of Dolichos lablab L. Seeds Food Chemistry, 38, 239-246. http://dx.doi.org/10.1016/0308-8146(90)90180-c

ELLIS, M. 1971. Dematiaceous Hyphomycetes. Commonwealth Mycol. Institute. Kew, Surrey, England, 601-608.

GILMAN, J. 1971. A Manual of Soil Fungi. Second edi. Lowa State. Univ. Press. 450 p.

GUPTA, O. 1997. Weed management. Principles and Practices Agro Botanica, Bikamer. 10.

HASAN, M.M., CHOWDHURY, S.P., ALAM, S., HOSSAIN, B., ALAM, M.S 2005. Antifungal effects of plant extracts on Seed-borne Fungi of wheat seed germination, seedling health and vigour index. Pakistan Journal of Biological Sciences, 8(9), 1284-1289. http://dx.doi.org/10.3923/pjbs.2005.1284.1289

HUMPHURES, L. 1995. Diversity of Productivity of Tropical Legumes. In Tropical Legumes in Animal Nutrition, D Mello JPF and C Devendra (eds.) CAB International, Wallingford, UK, 1-21.

JAIN, A., KHARE, N. 1972. Chemical control of Rhizoctonia bataticola causing diseases of urid Mysore. Journal of Agricultural Science, 6(4), 461-465.

JUKANTI, A.K., GAUR, P.M., GOWDA, C.L.L., CHIBBAR, R.N. 2012 Nutritional quality and health benefits of chickpea (Cicer arietinum L.): a review. British Journal of Nutrition, 108, 11-26. http://dx.doi.org/10.1017/s0007114512000797

KHAN, M., KUMAR, R. 1990. Antifungal activity of leaf extract of Neem on seed mycoflora of wheat. Indian Journal of Applied Pure Biology, 5(1), 13-14.

KHAN, A.A., JILANI, G., AKHTAR, M.S., NAQVI, S.M.S., RASHED, M. 2009. Phosphorous solubilizing bacteria: Occurance, Mechanisms and their role in crop production. Journal of Agriculture and Biological Sciences, 1, 48-58.

KHARE, A., SHETTY, S., SHETTY, H., SAFIULLAH. 1988. Trichoniella padwickii in Karnataka in relation to Environmental Factors. International Journal of Plant Disease, 6(1), 124-133.

LAMBAT, K., SIDDIQUI, R., RAMNATH, MAJUMDER, A., RANI, I. 1974 Seed-borne fungi of sugar beet in India with special reference to Phoma betae Frank and its control. Seed Research, 2, 33-40.

MALEKZADEH, F., SHABESTARI, P. 1989. Therapeutic effects and in vitro activity of an extract from Lawsonia inermis. Journal of Science Islamic Republic, 1(1), 7-12.

MISRA, S., DIXIT, S. 1977. Screening of some medicinal plants for antifungal activity. Geobios, 4, 129-132.

MOHADEVAN,A.,SRIDHAR, H. 1982. Methods in Physiological Plant Pathology. SecondEdi. Sivakami Publications, Madras, 316.

NAIDU, A., JOHN, V. 1981. In vitro inhibition of rice fungal pathogens by extracts from higher plants. In. Rice Research News, 6(5), 12.

NEERGAARD, P. 1980. A review of quarantine for seed. National Academy of Sciancas, India, Golden Jubilee Commemoration, 4, 495- 530.

REDDY, O., Khare, M. 1978. Seed-borne fungi in Madhya Prodesh and their significance. Indian Phytopathology, 31, 300-303.

SURATUZZAMAN, M., HOSSAIN, I., FAKIR, G. 1995. Studies on the seed borne fungi of soybean and its control. M. Sc. Ag. Thesis. Dept. of Plant Pathology. BAU, Mymensingh, Bangladesh, 58.

SANKARANARAYANAN, R., VIJAYAKUMAR, M., RANGASAMY, P. 1994. Cow urine for ideal seed germination in tamarind. Indian Horticulture, 38(4), 15 .
SINCLAIR, T.R., VADEZ, V. 2012. The future of grain legumes in cropping systems. Crop \& Pasture Science. http://dx.doi.org/10.1071/CP12128

SINGH, S., SINGH, N. 1986. Seed mycoflora of broad bean and its control. Indian Phytopath, 39(4), 541-543.www.ajebs.com/special/SP-35.pdf

SINGH, U., PANDEY. V., WAGNER, G,. SINGH, K. 1990. Antifungal activity of ajoene, a constituent of garlic (Allium sativum). Canadian Journal of Botany, 68(6) 1354-1356. http://dx.doi.org/10.1139/b90-172

WELLMAN, R. 1977. Problems in development registration and use of fungicides. Arn. Review Phytopathology, 15-153 http://dx.doi.org/10.1146/annurev.py.15.090177.001101

YUDE, C., KAIWEIi, H., FUJIi, L., JIE, Y. 1993. The potential and utilization prospects of kinds of wood fodder resources in Yunnan. Forestry Research, 6, 346-350. 